\title{
LIQUEFACTION BEHAVIOUR OF TWELVE TROPICAL HARDWOOD SPECIES IN PHENOL
}

\author{
Anil Kumar ${ }^{1}$, Anil Sethy, Shakti Chauhan ${ }^{1, \mathrm{~s}}$
}

\begin{abstract}
Liquefaction of ligno-cellulosic biomass is one of the chemical conversion technologies for developing new materials, adhesives and energy systems. The liquefaction process also provides an opportunity to utilize ligno-cellulosic wastes such as saw-dust, woody wastes, branches and twigs, agro-residues, etc. for the development of value added products. This paper presents the liquefaction behaviour of wood meal of twelve tropical hardwood species in phenol as liquefying media to produce chemically active liquid which has potential to be used as a raw material for developing different products. The liquefaction was carried out at $140^{\circ} \mathrm{C}$ temperatures for 120 minutes at different liquid ratios. In all the cases, a viscous and sticky black liquid was obtained after the stipulated reaction time. The liquefaction efficiency was found to vary with species and liquid ratio. The highest liquefaction efficiency of $93 \%$ was achieved in balsa wood at 1:3 (wood: phenol) liquid ratio. The liquefied wood and residues were characterized by FTIR spectroscopy. The liquefied wood was found to be highly acidic in nature. Viscosity of liquefied wood at higher liquid ratio was independent of wood species. Correlation analysis revealed a strong negative relationship between wood basic density and liquefaction efficiency.
\end{abstract}

Keywords: Ash content, density, extractives, Fourier transform infrared analysis, lignin, wood chemical properties.

\section{INTRODUCTION}

In recent years, the utilisation of lignocellulosic biomass has become appealing because of versatility, renewable nature and environmental concerns. One of the promising approaches of utilizing lignocellulosic wastes is its liquefaction and converting the liquefied wood into value added products (Worthy 1990). In liquefaction process, macromolecule compounds in biomass are degraded into micro molecules and the obtained small molecules are unstable, reactive and can re-polymerize into oily products with a wide range of molecular weight distribution (Demirbas 2000).

Strong network of cellulose, hemicellulose and lignin and the crystalline structure of some regions of cellulose make wood extremely resistant to liquefaction, even under severe reaction conditions. $\mathrm{Pu}$ and Shiraishi 1993, Pu and Shiraishi 1994) reported that liquefaction of lignocellulosic biomass wastes, especially in presence of organic solvents e.g. phenols, alcohols, glycols and ketones using acid catalysts at temperatures of $120^{\circ} \mathrm{C}-180^{\circ} \mathrm{C}$ or without catalysts at temperatures of $180^{\circ} \mathrm{C}-250^{\circ} \mathrm{C}$. Yao (1996), in his studies with birch wood, reported the initial stages rapid liquefaction due to dissolution of easily accessible components of lignin, hemicelluloses and cellulose, followed by the slow liquefaction

${ }^{1}$ Institute of Wood Science and Technology, Bengaluru, India.

"Corresponding author: shakti@icfre.org

Received: 17.01.2017 Accepted: 29.11.2017 
of hard-to-access cellulose. Thereafter several studies have been carried out on liquefaction of wood in different liquefaction systems and product development from liquefied wood (Alma et al. 1998, Alma and Acemioglu 2004, Yamazaki et al. 2006, Honglu and Tienju 2006, Lin et al. 2014, Petrič et al. 2015). Lin et al. $(2001,2004)$ have studied the mechanism of liquefaction of lignin model compound and cellulose in phenol to understand wood liquefaction mechanism.

Research on wood liquefaction has primarily focussed on effects of catalysts, solvents, temperature, and other factors on liquefaction efficiency. Studies on accelerating liquefaction using microwave and ultrasonication has also been attempted (Pan et al. 2011). In most of these studies, specific wood species has been used as the source of woody biomass.

Industrial woody wastes are generally mixtures of various wood species softwoods, hardwoods, composite wood, other ligno cellulosic material from forest, agricultural residues, weeds, shrubs, lops and tops of plantation species. Liquefaction behaviour of different species and, the physical and chemical properties of liquefied wood have not been studied much. Kurimoto et al. 1999, Kurimoto et al. 2001 reported strong influence of wood species on liquefaction process using Poly Ethylene Glycol as the liquefying agent at 3:1 liquid ratio and 120 minutes of reaction. The softwood species exhibited higher residual content as compared to hardwood species. Within hardwood species also significant differences were observed in liquefaction efficiency Ertas et al. (2014) compared liquefaction efficiency of Eucalyptus and pine wood in PEG-400/glycerine system and found significant differences in characteristics of liquefied wood from two species. Hardwood species are highly variable in terms of their anatomical structure, density and extractive content which can influence the liquefaction process. There is hardly any study on liquefaction process of tropical hardwood species. Chauhan and Karmarkar (2009) studied the liquefaction efficiency of Hevea brasiliensis wood in phenol with hydrochloric acid as a catalyst and found liquefaction efficiency of $49 \%$ to $82 \%$ under different reaction conditions.

In this study, liquefaction efficiency of 12 tropical hardwood species and their mixture was determined using phenol as the liquefying agent and $\mathrm{HCl}$ as the catalyst. The liquefaction was carried out at different liquid ratio. The liquefied wood was characterized for properties like viscosity and $\mathrm{pH}$. The wood characteristics namely wood density, ash content, extractive content, and lignin content were determined and related to liquefaction efficiency. The liquefied wood and residues were chemically characterized by FTIR spectroscopy.

\section{MATERIALS AND METHODS}

\section{Wood species and chemicals}

Wood species were selected based on various density classes and these were

I. Low Density class (below $500 \mathrm{~kg} / \mathrm{m}^{3}$ ): Ochroma pyramidale, Delonix regia

II. Moderate Density Class (500-650 kg/m³): Melia dubia, Leucania leucocephala, Hevea brasiliensis,

III. High Density Class (above $650 \mathrm{~kg} / \mathrm{m}^{3}$ ): Prosopis juliflora, Azardirachta indica, Tectona grandis, Eucalyptus tereticornis, Dalbergia latifolia, Terminalia tomentosa, Casuarina equesetifolia

\section{Mixture of all wood species}

Wood material of each of the selected species was collected from local sawmills and chipped into small pieces. The chips were air dried and pulverized using a laboratory scale pulveriser. The pulverized wood meal was sieved through 150 mesh sieve (BSS specification, $\sim 80 \mu \mathrm{m}$ particle size) and oven dried at $105^{\circ} \mathrm{C}$ for $24 \mathrm{~h}$.

Phenol (LR grade) was used as the liquefying media and hydrochloric acid (LR. Grade) was used as a catalyst. For characterizing the liquefied wood, laboratory grade reagents namely; 1-4 Dioxane, 
phthalic anhydride, pyridine, $\mathrm{KOH}$ and methanol were used. All the reagents and solvents were procured from Nice Chemicals, Kochi, India and used as received.

\section{Liquefaction of wood powder}

Oven dry sawdust of various wood species was used for the preparation of liquefied wood. Wood liquefaction was carried out in phenol as the dissolving agent and $\mathrm{HCl}$ as the catalyst. The liquid ratio i. e. wood to solvents ratio were 1:1, 1:2, 1:3 and catalyst content was $3 \mathrm{wt} \%$ of the wood content. Liquefaction reaction was performed for 120 minutes in a glass reactor equipped with a stirrer and a condenser. The reactor was immersed in an oil bath that was preheated to $140^{\circ} \mathrm{C}$. For each liquefaction reaction, $10 \mathrm{~g}$ of oven dried meal was taken in the glass reactor. The pre-determined quantity of phenol and $\mathrm{HCl}$ was added to the wood meal. The mixture was kept as such without any stirring at $140^{\circ} \mathrm{C}$ for 30 minutes. Thereafter, stirring was started and continued for 90 minutes. After the liquefaction reaction process, the liquefied wood was diluted thoroughly with excess methanol and filtered through glass filter paper under reduced pressure on G1 filtration apparatus. Methanol from the filtrate was recovered by distillation and the liquefied wood was obtained. The residues were dried in an oven at $105^{\circ} \mathrm{C}$ until it reached to a constant weight. Liquefaction efficiency (LE, \%) was calculated from the initial weight of wood meal and residual weight using Equation 1.

$$
\operatorname{LE}(\%)=\frac{m_{0}-m_{1}}{m_{0}} \times 100
$$

Where $m_{0}$ is oven-dry weight of the initial wood $(\mathrm{g})$ and $m_{1}$ is oven-dry weight of the residue content (g).

\section{Viscosity of the Liquefied wood}

The viscosity of the liquefied wood was measured using a Ford viscosity cup $\mathrm{N}^{\circ} .4$ (B4 cup). The viscosity cup was fully filled with the liquid under the test, and the flow time through standard orifice was measured. Equation 2 was used to convert the time of flow in seconds, $t$ to kinematic viscosity V4;

$$
V 4=3,85(t-4,49)
$$

Where; V4= kinematic viscosity using orifice $\mathrm{N}^{\circ} 4$ and $\mathrm{t}$ is flow time of liquid through orifice in seconds

\section{FTIR analysis of the Liquefied wood and residues}

The changes of components of the liquefied biomass based polyols during the liquefaction were analyzed using Bruker make Fourier transform infrared (FTIR) spectrometer (Tensor 27 model). Spectra were recorded for wood meal, liquefied wood and wood residue, with a co-addition of 64 scans at a spectral resolution of $4 \mathrm{~cm}^{-1}$. Each spectrum was recorded in a frequency range of 400-4000 $\mathrm{cm}^{-1}$ using potassium bromide $(\mathrm{KBr})$ disc. $\mathrm{KBr}$ was previously oven-dried at $105^{\circ} \mathrm{C}$ to reduce the interference of water.

\section{Wood chemical analysis}

Wood meal of all the studied species was analyzed for ash content, extractive content and lignin content. For ash content estimation, $10 \mathrm{~g}$ wood sample (oven dried and cooled) was weighed in a ceramic crucible and kept in a muffle furnace at $650^{\circ} \mathrm{C}$ for 8 hours. Ash content was determined from the initial and final weight of the sample. Extractive content was determined by extracting $10 \mathrm{~g}$ wood 
meal (oven dried and cooled) with a mixture of toluene, acetone and ethanol (4:1:1 wt ratio) using soxhelet extraction until colour less solution in the extraction unit was obtained. The extractive free wood was oven dried and weighed. Extractive content was estimated from the initial weight and final weight after extraction. Lignin estimation was carried out from the extractive free wood as per Tappi method (T222-om 15:1988). Air-dry density of wood was determined from the air-dried mass and volume of wood samples of each species.

\section{RESULTS AND DISCUSSION}

Wood characteristics namely air dry density, ash content, extractive content and lignin content of the species are given in Table 1. Wood density among the species was varying from $178 \mathrm{~kg} / \mathrm{m}^{3}$ to 831 $\mathrm{kg} / \mathrm{m}^{3}$. Ash content was ranging from $0,84 \%$ to $5,27 \%$ extractive content was ranging from $1,92 \%$ to $16,81 \%$ and acid-insoluble lignin content was ranging from $18,84 \%$ to $31,86 \%$.

Table 1. Air-dry density, ash content, extractive content and lignin content in wood.

\begin{tabular}{|c|l|c|c|c|c|}
\hline No. & \multicolumn{1}{|c|}{ Species } & $\begin{array}{c}\mathrm{AD} \text { density } \\
\left(\mathrm{kg} / \mathrm{m}^{3}\right)\end{array}$ & $\begin{array}{c}\text { Ash content } \\
(\%)\end{array}$ & $\begin{array}{c}\text { Extractive } \\
\text { content } \\
(\%)\end{array}$ & $\begin{array}{c}\text { Lignin content } \\
(\%)\end{array}$ \\
\hline 1 & Ochroma pyramidale & 178 & 1,69 & 1,92 & 18,84 \\
\hline 2 & Delonix regia & 432 & 5,09 & 7,42 & 29,59 \\
\hline 3 & Melia dubia & 510 & 0,84 & 8,11 & 31,86 \\
\hline 4 & Hevea brasilensis & 535 & 1,17 & 6,66 & 21,17 \\
\hline 5 & Lecanea leucocephala & 578 & 2,00 & 10,49 & 28,75 \\
\hline 6 & Prosopis juliflora & 655 & 2,04 & 9,94 & 28,75 \\
\hline 7 & Eucalyptus treticornis & 668 & 1,79 & 10,20 & 27,08 \\
\hline 8 & Tectona grandis & 675 & 2,30 & 11,76 & 29,40 \\
\hline 9 & Azardirachta indica & 692 & 3,84 & 8,02 & 31,17 \\
\hline 10 & Dalbergis latifolia & 737 & 5,27 & 13,31 & 30,91 \\
\hline 11 & Casurina equesetifolia & 773 & 1,11 & 9,49 & 30,83 \\
\hline 12 & Terminalia tomentosa & 831 & 2,50 & 16,81 & 31,84 \\
\hline
\end{tabular}

The liquefaction efficiency and characteristics of liquefied wood namely viscosity and $\mathrm{pH}$ at different liquid ratio are given in Table 2. Within a species, liquefaction efficiency increased with the increasing liquid ratio. The role of solvent is to dissolve the liquefied products and prevent them from re-polymerizing. At lower liquid ratio, during the initial stages of the process, the dissolving agent was wetting only a small part of wood meal and the stirring was difficult in the reactor vessel. However as the reaction proceeded with slow and careful stirring for longer time, it resulted in photolysis of lignin which initiated the liquefaction process resulting in satisfactory liquefaction. Liquefaction efficiency of $68,89 \%$ to $78,53 \%$ was achieved for different species at $1: 1$ liquid ratio.

At 1:2 liquid ratio, there was no concern with respect to stirring as the quantity of phenol was enough to wet wood surface and the liquefaction reaction proceeded smoothly. The liquefaction efficiency at this liquid ratio was nearly $10 \%$ higher than as observed at $1: 1$ liquid ratio. Increasing phenol content further at 1:3 liquid ratio did not result in any remarkable increase in the liquefaction efficiency. At 1:3 liquid ratio, the liquefaction efficiency was only about $3-4,5 \%$ higher than at $1: 2$ liquid ratio irrespective of species. Overall, liquefaction efficiency of wood varied from $69 \%$ to $93 \%$ under different reaction conditions and at different liquid ratio. Chauhan and Karmarkar (2009) observed 
$77 \%$ liquefaction efficiency of rubber wood in phenol with $1: 3$ liquid ratio at $140^{\circ} \mathrm{C}$ which was lower than the observed liquefaction of the same species in this study. Liquefaction efficiencies for birch wood was reported to be of $90 \%$ and $100 \%$ in the presence of hydrochloric and sulphuric acid catalyst respectively at $150^{\circ} \mathrm{C}$ in two hours of reaction (Acemioglu and Alma 2002, Alma and Acemioglu 2004) which is in agreement with this study. Lee and Chen (2008) also reported 82\% liquefaction of Japanese cedar in phenol at 1:2.5 liquid ratio with $\mathrm{HCl}$ as catalyst with reaction carried out at $130^{\circ} \mathrm{C}$. The liquefaction with sulphuric acid catalyst was nearly $95 \%$ under the same conditions. Hrastnik et al. (2013) obtained more than $90 \%$ liquefaction efficiency of black poplar wood at liquid ratio of $1: 3$ and more with ethylene glycol as the liquefying media and they did not find any significant improvement in liquefaction efficiency on increasing the liquid ratio beyond 1:3.

Among the species, the highest liquefaction efficiency was achieved in Ochroma pyramidales and the lowest was in Terminalia tomentosa at all the liquid ratios. These species were also found to be having the extreme values in terms of wood density, extractive content and lignin content. It was observed that high density wood exhibited relatively low liquefaction efficiency as compared to low density wood. However, it is to be noted that the liquefaction efficiency at 1:3 liquid ratio was varying within a small range from $83 \%$ to $93 \%$ though the air dry density was varying from $178 \mathrm{~kg} / \mathrm{m}^{3}$ to 831 $\mathrm{kg} / \mathrm{m}^{3}$, exhibiting nearly five- fold variation (Table 1 ).

The small difference in liquefaction efficiency of wood having extreme density differences may be attributed to the differences in anatomical structure and permeability which may influence the penetration of phenol in cell-walls and the mechanism of wood liquefaction. Once the depolymerisation of lignin takes place in the initial stages, the liquefaction process gets accelerated resulting in rapid liquefaction of other components of wood cell walls. This suggests that satisfactory liquefaction of wood can be achieved irrespective of wood species and density. This is further substantiated with the viscosity of the liquefied wood. At low liquid ratio i.e. 1:1 the viscosity of Ochroma pyramidales and Delonix regia liquefied wood was significantly lower than other species and this may be attributed to easy penetration of phenol into the cell wall resulting in rapid liquefaction of these two species. The viscosity at 1: 1 liquid ratio was ranging from $51,44 \mathrm{cp}$ to $132,18 \mathrm{cp}$ in different species. However at 1:3 liquid ratio, the viscosity of liquefied wood from different species was not varying much with its value ranging from 32,34 to $44,86 \mathrm{cp}$.

The $\mathrm{pH}$ value of liquefied wood is an indicator of hydrogen ions activity. $\mathrm{pH}$ value varied from 2,14 to 3,87 at $1: 1$ liquid ratio 1,84 to 2,86 at $1: 2$ liquid ratio and $1,53-2,16$ at liquid ratio $1: 3$. Within a species, $\mathrm{pH}$ values declined with increasing liquid ratio indicating that acidity increases with increase in phenol content. This was expected as the liquefied wood ought to be more acidic with more phenol.

Table 2. Effects of species on liquefaction efficiency at different liquid ratio.

\begin{tabular}{|l|l|l|l|l|l|l|l|l|l|l|}
\hline \multirow{2}{*}{ No. } & \multirow{2}{*}{ Species } & \multicolumn{2}{|l|}{ Liquefaction efficiency (\%) } & \multicolumn{3}{|c|}{ Viscosity $(\boldsymbol{c}$ ) } & \multicolumn{3}{c|}{ pH } \\
\cline { 3 - 10 } & $\begin{array}{l}\text { Liquid } \\
\text { ratio } \\
\mathbf{1 : 1}\end{array}$ & $\begin{array}{l}\text { Liquid } \\
\text { ratio } \\
\mathbf{1 : 2}\end{array}$ & $\begin{array}{l}\text { Liquid } \\
\text { ratio } \\
\mathbf{1 : 3}\end{array}$ & $\begin{array}{l}\text { Liquid } \\
\text { ratio } \\
\mathbf{1 : 1}\end{array}$ & $\begin{array}{l}\text { Liquid } \\
\text { ratio } \\
\mathbf{1 : 2}\end{array}$ & $\begin{array}{l}\text { Liquid } \\
\text { ratio } \\
\mathbf{1 : 3}\end{array}$ & $\begin{array}{l}\text { Liquid } \\
\text { ratio } \\
\mathbf{1 : 1}\end{array}$ & $\begin{array}{l}\text { Liquid } \\
\text { ratio } \\
\mathbf{1 : 2}\end{array}$ & $\begin{array}{l}\text { Liquid } \\
\text { ratio } \\
\mathbf{1 : 3}\end{array}$ \\
\hline 1 & Ochroma pyramidales & 78,53 & 88,36 & 93,02 & 51,44 & 42,20 & 32,34 & 3,6 & 2,8 & 1,86 \\
\hline 2 & Delonix regia & 77,15 & 86,59 & 91,30 & 77,11 & 54,05 & 33,61 & 2,73 & 2,34 & 1,85 \\
\hline 3 & Melia dubia & 76,29 & 86,25 & 90,78 & 99,83 & 87,93 & 44,01 & 3,02 & 2,86 & 2,16 \\
\hline 4 & Hevea brasilensis & 75,46 & 85,84 & 89,41 & 114,99 & 85,00 & 42,19 & 3,87 & 2,47 & 1,79 \\
\hline 5 & $\begin{array}{l}\text { Leucania } \\
\text { leucocephala }\end{array}$ & 74,26 & 84,98 & 88,69 & 116,60 & 93,23 & 44,86 & 3,86 & 2,78 & 1,97 \\
\hline 6 & Prosopis juliflora & 73,14 & 84,16 & 87,52 & 132,18 & 90,39 & 34,38 & 2,86 & 2,57 & 1,96 \\
\hline 7 & Eucalyptus treticomis & 72,85 & 83,79 & 87,17 & 102,52 & 78,46 & 33,22 & 2,38 & 2,18 & 1,84 \\
\hline 8 & Tectona grandis & 72,37 & 83,20 & 86,46 & 96,60 & 73,50 & 34,38 & 2,92 & 2,42 & 1,93 \\
\hline 9 & Azardirachta indica & 71,41 & 82,68 & 85,79 & 97,60 & 71,88 & 32,65 & 2,87 & 2,62 & 1,83 \\
\hline 10 & Dalbergia latifolia & 71,01 & 81,60 & 85,15 & 97,68 & 91,44 & 42,47 & 2,78 & 2,42 & 1,93 \\
\hline 11 & $\begin{array}{l}\text { Casuarina } \\
\text { equesetifolia }\end{array}$ & 70,59 & 80,54 & 84,35 & 98,01 & 72,46 & 44,81 & 2,19 & 1,98 & 1,78 \\
\hline 12 & Terminalia tomentosa & 68,89 & 79,57 & 83,09 & 97,71 & 89,20 & 40,75 & 2,14 & 1,84 & 1,64 \\
\hline 13 & Mixed hard wood & 73,93 & 84,61 & 88,26 & 129,26 & 96,97 & 34,65 & 2,27 & 1,97 & 1,88 \\
\hline
\end{tabular}


A correlation analysis was performed to understand the relationship between different parameters of the liquefied wood and wood characteristics. Table 3 represents the Pearson's correlation coefficients for 1:1, 1:2 and 1:3 liquid ratios with wood density, ash content, extractive content and lignin content.

Table 3. Pearson's correlation coefficients of liquefied wood parameters with wood characteristics. (ADD- air dry density, AC- Ash content, EC- extractive content, LC- lignin content, LE- liquefaction efficiency, V- Viscosity. Notation 1,2, 3 represents liquid ratio of 1:2, 1:2 and 1:3, respectively).

\begin{tabular}{|c|c|c|c|c|c|c|c|c|c|}
\hline Variable & LE1 & LE2 & LE3 & V1 & V2 & V3 & pH1 & $\mathrm{pH} 2$ & pH3 \\
\hline ADD & $-0,95^{* *}$ & $-0,94^{* *}$ & $-0,96^{* *}$ & $0,60^{*}$ & $0,67^{*}$ & 0,32 & $-0,63^{*}$ & $-0,64^{*}$ & $-0,29$ \\
\hline $\mathrm{AC}$ & $-0,15$ & $-0,16$ & $-0,15$ & $-0,22$ & $-0,14$ & $-0,28$ & $-0,21$ & $-0,10$ & $-0,13$ \\
\hline $\mathrm{EC}$ & $-0,83^{* *}$ & $-0,83^{* *}$ & $-0,82^{* *}$ & 0,46 & $0,69^{*}$ & 0,33 & $-0,56$ & $-0,60^{*}$ & $-0,23$ \\
\hline LC & $-0,63^{*}$ & $-0,65^{*}$ & $-0,61^{*}$ & 0,34 & 0,47 & 0,27 & $-0,64^{*}$ & $-0,31$ & 0,15 \\
\hline
\end{tabular}

Liquefaction efficiency exhibited a strong negative relation with wood density at all liquid ratios. Wood density exhibited significant positive correlation with viscosity, and negative correlation with $\mathrm{pH}$ of liquefied wood at 1:1 and 1:2 liquid ratio but these relationships were not apparent at 1:3 liquid ratio. The varying correlation with liquid ratio may be attributed to limited liquefaction at low phenol content during the stipulated reaction time. Ash content of wood was not found to be associated with liquefaction efficiency and other liquefied wood parameters. Extractive content and lignin content of species were negatively correlated to liquefaction efficiency at all liquid ratio. Higher extractive and lignin content may hinder the penetration of phenol into the cell-wall ultra-structure and consequently slow defragmentation of cell-wall constituents. Wood density was positively correlated to extractive content $(\mathrm{r}=0,86)$ and lignin content $(\mathrm{r}=0,72)$ which was on the expected lines. There was no consistent correlation of viscosity and $\mathrm{pH}$ of liquefied wood with extractive content. Therefore any relationship observed at a specific reaction condition may not be generalized. No significant correlation was observed between viscosity and $\mathrm{pH}$ of liquefied wood at all liquid ratio.

The results suggest that wood species irrespective of having different densities can be liquefied at higher liquefying agent concentration without any significant influence on characteristics of liquefied wood and therefore mixing of wood species may not any significant impact on characteristics of liquefied wood. This is evident from the fact that for mixed hardwood species the liquefaction efficiency of $88 \%$ was achieved at 1:3 liquid ratio and other characteristics of liquefied wood were close to the average of species.

\section{FTIR Characterization}

FTIR spectra of wood and residuals shown in Figure 1 have been evaluated into two regions namely $3800-2700 \mathrm{~cm}^{-1}$ which is assigned to the $\mathrm{O}-\mathrm{H}$ and $\mathrm{C}-\mathrm{H}$ stretching vibrations and the $1800-900$ $\mathrm{cm}^{-1}$ fingerprint region assigned to stretching vibrations of wood components. A strong broad band at $3000-3600 \mathrm{~cm}^{-1}$ is related to $\mathrm{O}-\mathrm{H}$ stretching and a band at $2800-3000 \mathrm{~cm}^{-1}$ is related to asymmetric methyl and methylene stretching groups present in the wood (Poletto 2017). In the fingerprint region, band at $1740 \mathrm{~cm}^{-1}$ is assigned to non-conjugated carbonyl group in hemicellulose and the band at $1510 \mathrm{~cm}^{-1}$ and $1610 \mathrm{~cm}^{-1}$ have their origin in the aromatic ring of lignin. The bands at $1375 \mathrm{~cm}^{-1}$, $1160 \mathrm{~cm}^{-1}$ and $898 \mathrm{~cm}^{-1}$ are mainly due to carbohydrates, while the band at $1460 \mathrm{~cm}^{-1}$ is attributed to syringyl aromatic skeletal vibration and $1220 \mathrm{~cm}^{-1}$ is assigned to guaiacyl ring breathing with carbonyl stretching (Pandey and Vuorinen 2008, Poletto et al. 2012). 


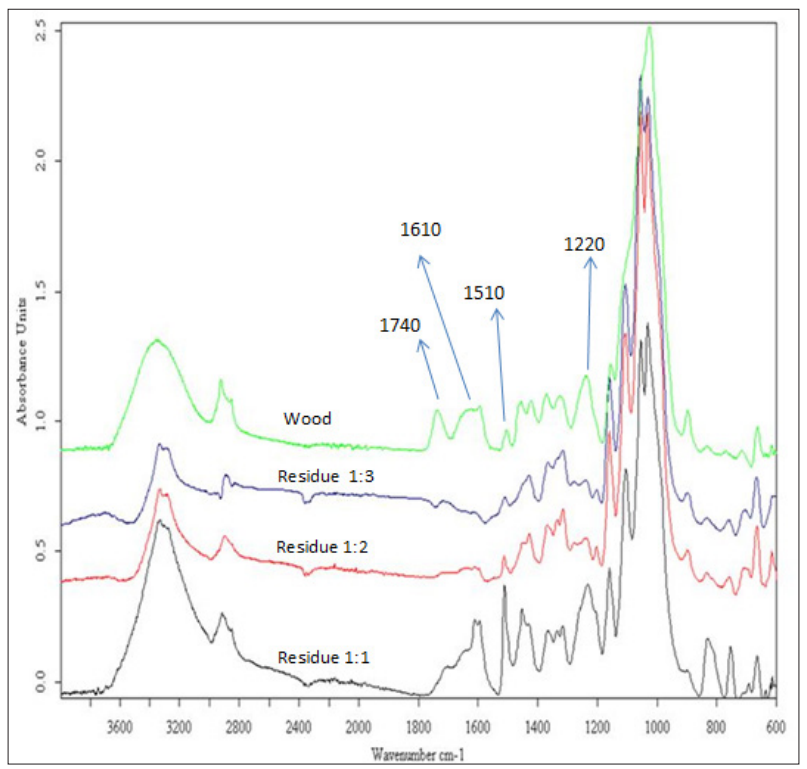

Figure 1. FTIR spectra of wood and residues obtained on liquefaction at 1:1, 1:2 and 1:3 liquid ratio.

In case of residues, the carbonyl peak intensity at $1740 \mathrm{~cm}^{-1}$ has almost disappeared indicating the dissolution of hemicellulose component of wood. The characteristic peaks associated with lignin (1510 $\mathrm{cm}^{-1}, 1610 \mathrm{~cm}^{-1}, 1460 \mathrm{~cm}^{-1}$ and $1220 \mathrm{~cm}^{-1}$ ) have also shown marked reduction in the wood residues particularly obtained with 1:2 and 1:3 liquid ratios. Pan et al. (2007) has also reported disappearance of peak at $1735 \mathrm{~cm}^{-1}$, attributed to the ester carbonyl group in xylan, in the FTIR spectra of the residues from liquefied wood. They observed reduction in the Klason lignin content and increase holocellulose and $\alpha$-cellulose contents as the phenol to wood ratio $(\mathrm{P} / \mathrm{W})$ increased. At 1:1 liquid ratio, peak corresponding to aromatic vibration stretching are visible and this may be attributed to incomplete liquefaction of lignin components and also presence of phenol in the wood residues.

The spectra of wood polyols at different liquid ratio (Figure 2) differ significantly from the spectra of wood residues and wood (Figure 1) and shows that almost all peaks gradually become stronger with increase in liquid ratio i.e. from $1: 1$ to $1: 2$ and 1:3.

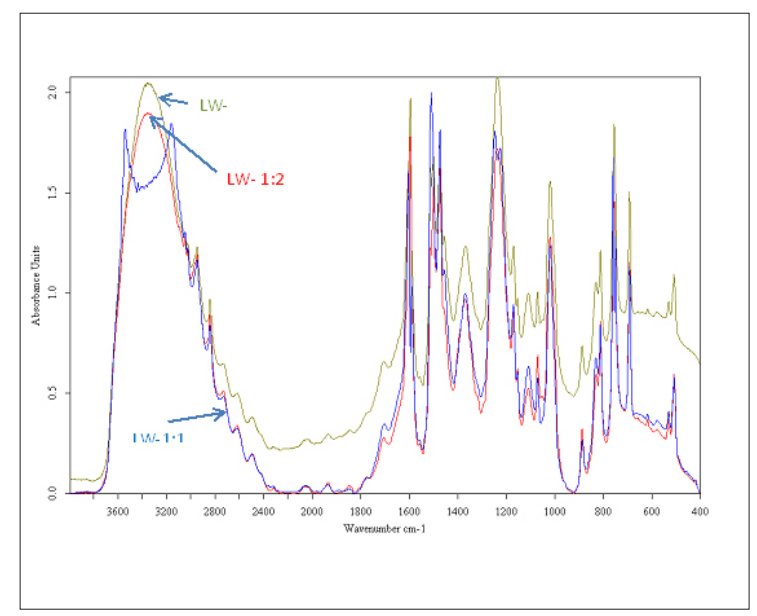

Figure 2. FTIR spectra of the liquefied wood at different liquid ratio. 
The spectra at 1:1 and 1:2 were nearly overlapping in the fingerprint region. The liquefied wood had peaks associated with both carbohydrate $\left(1740 \mathrm{~cm}^{-1}, 1375 \mathrm{~cm}^{-1}\right)$ and lignin components $(1610 \mathrm{~cm}$ $\left.{ }^{1}, 1510 \mathrm{~cm}^{-1}, 1220 \mathrm{~cm}^{-1}\right)$ and therefore is an indicative of liquefaction of all the components of wood. The spectral analysis clearly indicates that almost all the component of wood converted into liquefied wood polyols.

\section{CONCLUSIONS}

The study revealed that wood meal from different hardwood species can effectively be liquefied in phenol using $\mathrm{HCl}$ as a catalyst with liquefaction efficiency ranging from $69 \%$ to $93 \%$ under similar reaction. With increasing phenol content, liquefaction efficiency increased but the liquefied wood was more acidic in nature. Extractive content had an adverse impact on liquefaction efficiency. Viscosity and $\mathrm{pH}$ value will help in deciding further processing for developing products from liquefied wood. Although wood density was correlated negatively with liquefaction efficiency but the range is relatively narrow. FTIR spectra suggest complete dissolution of lignin and hemicelluloses and the residuals are mainly the crystalline cellulose. It is desirable to have high liquefaction efficiency at a low liquid ratio to make liquefied wood economical and 1:2 liquid ratios appears to be effective in achieving satisfactory liquefaction. The liquefied wood polyols having huge potential as a raw material for development of value added products adhesive, energy, preservative and materials.

\section{ACKNOWLEDGEMENTS}

Authors express sincere gratitude to the Director and Group Coordinator Research, Institute of Wood Science and Technology, Bengaluru and the Head, Wood Processing Division for their support and encouragement in carrying out this study. The authors are also thankful to the Indian Council of Forestry Research and Education, Dehradun for the financial support to this research.

\section{REFERENCES}

Acemioglu, B.; Amla, M.H. 2002. Kinetics of wood phenolysis in the presence of $\mathrm{HCl}$ as catalyst. Journal of Applied Polymer Science 64(2):1098-1103.

Alma, M. H.; Acemioglu, B. 2004. A kinetic study of sulfuric acid catalyzed liquefaction of wood into phenol. Chem Eng Commun 191(7): 968-980.

Alma, M.H.; Maldas, D.; Shiraishi, N. 1998. Liquefaction of several biomass wastes into phenol in the presence of various alkalis and metallic salts as catalysts. Journal of Polymer Engineering 18: $162-177$

Chauhan, S.S.; Karmarkar A. 2009. Studies on Liquefaction efficiency of Hevea brasilensis wood in phenol with hydrochloric acid as a catalyst. Journal of Institute of Wood Science 19:22-26.

Demirbas, A. 2000. Mechanisms of liquefaction and pyrolysis reactions of biomass. Energy Convers Mgmt 41:633-646. 
Ertas, M.; Fidan, M; Alma, M.H. 2014. Preparation and characterization of biodegradable rigid polyurethane foams from the liquefied eucalyptus and pine woods. Wood Research 59(1): 97-108.

Hrastnik, D; Budija, F; Humar, M; Petric, M. 2013. Influence of liquefied and CCB containing liquefied wood on growth of wood decay fungi. Maderas-Cienc Tecnol 15(1): 105-118.

Honglu X; Tiejun S., 2006. Wood liquefaction by ionic liquids. Holzforschung 60(5): 509-512.

Kurimoto, Y.; Doi, S.; Tamura, Y. 1999. Species effects on wood-liquefaction in polyhydric alcohols. Holzforschung 53: 617-622.

Kurimoto, Y.; Koizumi, A.; Doi, S.; Tamura, Y.; Ono, H. 2001. Wood species effects on the characteristics of liquefied wood and the properties of polyurethane films prepared from the liquefied wood. Biomass and Bioenergy 21(5): 381-390.

Lee, W.J; Chen, Y.C. 2008. Novolak PF resins prepared from phenol liquefied Cryptomeria japonica and used in manufacturing moldings. Bioresource Technology 99: 7247-7254.

Lin, R.; Sun, J.; Yue, C.; Wang, X.; Tu, D.; Gao, Z. 2014. Study on preparation and properties of phenol-formaldehyde-chinese fir liquefaction copolymer resin. Maderas-Cienc Tecnol 16(2): 159174.

Lin, L.; Yao, Y.; Yoshioka, M.; Shiraishi, N. 2001. Liquefaction mechanism of $\beta-O-4$ lignin model compound in the presence of phenol under acid catalysis. Part 2. Reaction behaviour and pathway. Holzforschung 55: 625-630.

Lin, L.; Yao, Y.; Yoshioka, M.; Shiraishi, N. 2004. Liquefaction mechanism of cellulose in the presence of phenol under acid catalysis. Carbohy Polym 57: 123-129.

Pan, H; Zheng, Z.; Hse, C.Y. 2011. Microwave-assisted liquefaction of wood with polyhydric alcohols and its application in preparation of polyurethane (PU) foams. European Journal of Wood and Wood Products 69(3):1-10.

Pan, H.; Shupe, T.; Hse, C.Y. 2007. Characterization of liquefied wood residues from different liquefaction conditions. Journal of Applied Polymer Science 105(6): 3740-3746.

Pandey, K. K.; Vuorinen, T. 2008. Comparative study of Photodegradation of wood by a UV laser and xenon light source. Polymer Degradation and Stability 93: 2138-2146.

Petrič M.; Ugovšek, A; Sernek, M. 2015. Bonding and surface finishing of wood with liquefied wood. Pro Ligno 11(4): 239-245.

Poletto, M.; Zattera, A.J.; Santana, R.M. 2012. Structural differences between wood species: evidence from chemical composition, FTIR spectroscopy, and thermo gravimetric analysis. Journal of Applied Polymer Science 126:E336-E343.

Poletto, M. 2017. Comparative study of wood flour photodegradation of two wood species submitted to artificial weathering. Maderas-Cienc Tecnol 19(2): 141-148.

Pu, S.; Shiraishi, N. 1993. Liquefaction of wood without a catalyst-I time course of wood liquefaction with phenols and effects of wood/phenol ratios. Mokuzai Gakkaishi 39(4): 446-452.

Pu, S.; Shiraishi, N. 1994. Liquefaction of wood without a catalyst IV. Effect of additives, such as acid, salt, and neutral organic solvent. Mokuzai Gakkaishi 40(8): 824-829.

Tappi 1988. Acid-insoluble lignin in wood and pulp. Test Method T 222 om-15.

Worthy, W. 1990. Lignocelluloses promise improved products for materials industries. Chemical Engg News 15: 19.

Yamazaki, J.; Minami, E.; Saka S 2006. Studies on the liquefaction of beach wood using supercritical alcohols. $J$ Wood Sci 52(6): 527-532. 
Yao, Y. 1996. Liquefaction of wood and other biomass in the presence of alcohols and its application. Doctor's thesis, Faculty of Agri., Kyoto Univ. pp. 6-33. 